\title{
Optical aids for low vision: use of the Internet to guide teachers of the visually impaired
}

\section{Auxílios ópticos para baixa visão: uso de internet na orientação de professores de deficientes visuais}

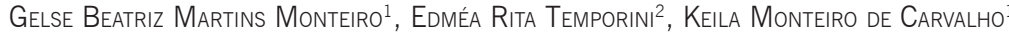

\begin{abstract}
Purposes: To describe and interpret teachers' opinions about and responsiveness to guidance on optical aids for low vision.

Methods: It was conducted a cross-sectional analytical study. The convenience, non-random sample consisted of 58 teachers from the public school network of the city of Campinas. It was constructed and applied a structured questionnaire, available online at the assessed website. For qualitative data collection it was conducted an exploratory study using the focus group technique.

Results: Responses expressed, for the most part, a marked interest in the website, its easiness of access, and the comprehensive nature of the information provided. Most people reported frequent use of the Internet to seek information, and found it easier to access the Internet at home. Among the qualitative aspects of the evaluation, we should mention the perceived importance of the website as a source of information, despite some criticism about the accessibility and reliability of the information found on the Internet.

Conclusion: Teachers' need for training to deal with visually impaired students and their positive response to advice and information lead to the conclusion that webbased guidelines on the use of optical aids were considered beneficial to ease the understanding of visual impairment and the rehabilitation of the affected subjects.
\end{abstract}

Keywords: Vision, low; Internet; Eye health; Health education; rehabilitation; Self-help devices; Visually impaired persons/education

\section{RESUMO}

Objetivos: Descrever e interpretar opiniões e receptividade de professores a orientações sobre auxílios ópticos para baixa visão.

Métodos: Caracterizou-se comoestudo transversal analítico. A amostraporconveniência, não randômica, foi constituída por 58 professores do sistema público de ensino, no município de Campinas. Aplicou-se questionário estruturado, disponibilizado on-line no site objeto de estudo. Realizou-se também estudo exploratório de abordagem qualitativa, com aplicação da técnica de grupo focal.

Resultados: Predominaram as opiniões de muito interesse no site; facilidade e suficiência de informações oferecidas. A maioria reportou uso frequente da internet para buscar informações; consideraram mais fácil acessar a internet na própria residência. Quanto aos aspectos qualitativos da avaliação, evidenciou-se o reconhecimento da importância do site como fonte de informações, embora existissem restrições quanto à facilidade de acesso e confiabilidade de informações veiculadas na internet.

Conclusão: A necessidade de preparo em relação à deficiência visual, declarada pelos professores e a receptividade a orientações e informações, permitem concluir pelo benefício de orientações divulgadas pelo website sobre uso de auxílios ópticos, o que facilita a compreensão de problemas visuais e a reabilitação em baixa visão.

Descritores: Baixa visão; Internet; Saúde ocular; Educação em saúde; Equipamentos de auto-ajuda; Pessoas com deficiência visual/educação

\section{INTRODUCTION}

Low vision refers to degrees of visual loss (between 0.3 and 0.05 ) in which individuals can be significantly helped by optical aids and resources. Visual function is the term used to describe the person's ability to use vision in the activities of daily living. Functionally speaking, people with low vision can use their residual vision to carry out their daily routine, to attend school and to maintain their social relationships, i.e., for social and educational integration ${ }^{(1,2)}$.

Visual rehabilitation aims at promoting the development and self sufficiency of people with low vision and is, therefore, targeted at the functional alterations of eye disorders and their implications in daily life and school learning. Ophthalmologists prescribe the use of assistive technologies, i.e. optical (magnifying lenses, telescopes) and non-optical (environmental changes) aids that facilitate education ${ }^{(3)}$.
In Brazil, the National Education Policy ensures the inclusion of persons with special needs in the regular education system. The fundamental principle of inclusive education is that all children should learn together, regardless of any difficulties or differences they may have, according to an educational concept open to individual characteristics and providing specialized educational support to students with special needs ${ }^{(4)}$.

Recent studies in the field of ophthalmology have stressed the importance of assistive technology resources, such as learning tools for visually impaired students, and confirmed the need for better trained teachers to perform these tasks ${ }^{(5)}$.

The regular school teacher who receives a visually impaired student faces a multifaceted challenge. He/she needs to know what type of disability the student has - blindness or low vision - how useful is the
Funding: No specific financial support was available for this study

Disclosure of potential conflicts of interest: G.B.M.Monteiro, None; E.R.Temporini, None; K.M.de Carvalho, None.

Correspondence address: Gelse Beatriz Martins Monteiro. Rua São Vicente de Paulo, 650/54 - São Paulo (SP) - 01229-010 - Brazil - E-mail: gelsebeatriz@gmail.com

Paper based on the PhD thesis "Optical aids for low vision: the use of the Internet by teachers of people with visual impairment", presented for defense at the University of Campinas Faculty of Medical Sciences in 2010.

Website www.auxiliosopticos.fcm.unicamp.br developed by Low Vision Clinic Research Group of the University of Campinas, Faculty of Medical Sciences General Hospital.

Study approved by Research Ethics Committee of the University of Campinas, under the number 298/2005 (Addendum 2006). 
residual vision, if any, what materials and resources can help the student, and how to deal with social prejudice and family issues ${ }^{(6)}$. Knowledge about this complex and specific subject should be promptly available, since this is no routine matter.

The educational use of the Internet is a growing trend among students and teachers and has been the focus of attention in the healthcare community, especially in ophthalmology, where eye care programs have been tailored to teachers of visually impaired students ${ }^{(7)}$. In addition, web-based physical activity behavior change programs have shown good results ${ }^{(8,9)}$. Positive attitudes were also perceived regarding the benefits of websites designed to help healthcare professionals in educating patients with chronic diseases, which encouraged the use of Internet portals in the management of these patients ${ }^{(10)}$.

The collaborative work of ophthalmology services specializing in low vision and schools contributes to the effectiveness of the rehabilitation process, since prescriptions are targeted to practice, i.e. to the school ${ }^{(11)}$.

Recent research studies on the use of information and communication technology in ophthalmology were the basis for the development of the Optical Aids website (www.auxiliosopticos.fcm.unicamp. br) - an educational program that provides information to families and teachers of visually impaired students (Figure 1).

Once the website was developed and published, we conducted the present survey in order to report and interpret the opinions and responsiveness of teachers to the guidance on optical aids for low vision and their use in the classroom.

\section{METHODS}

The study was designed as a cross-sectional analytical study based on the Optical Aids website providing orientation on low vision. It was constructed and applied a structured questionnaire, available on-line at the assessed website for data collection.

The theoretical content of the website was based on studies conducted at the University ${ }^{(3)}$, websites of international agencies containing information on eye health, expertise gathered from the low vision management clinic, in addition to illustrations and films specifically designed for the program. Topics addressed include visual impairment, low vision, use of optical and non-optical devices in the classroom, behavior of visually impaired teenagers and links of interest (Figure 1).
The sample consisted of 58 teachers from the public school system in the municipality of Campinas. The school inclusion criteria were established considering the low incidence of visually impaired students in the region, i.e. from the 84 schools of the region, we selected nine schools in which there were visually impaired students and five in which there were no such cases.

It was also conducted a qualitative study, using the focus group technique - a discussion with a small group of people who share common interests related to the topic. The purpose of this activity was to identify qualitative issues that might be spontaneously and effectively expressed by the subjects when the study takes place in the natural setting ${ }^{(12)}$. The focus group included teachers with and without visually impaired students, those working in resource rooms for the visually impaired, and teachers who held positions in education coordination and supervision. The meeting was videotaped and transcribed to allow for categorization of the information obtained.

The study was approved by the Research Ethics Committee/ Investigational Review Board of the University, under the number 298/2005 (Addendum 2006), and the subjects have read and signed an Informed Consent Form, as a precondition to completion of the on-line questionnaire.

\section{RESULTS}

All teachers who have received guidance on the use of optical aids for students with low vision through the website completed the online questionnaire, providing a sample of 58 subjects, of which $91.4 \%$ were teachers and $8.6 \%$ were educational coordinators. From the respondents, $62.7 \%$ reported teaching students with visual impairment.

According to $81.3 \%$ of teachers with and $73.7 \%$ without visually impaired students, the website was very interesting; $64.5 \%$ and $73.7 \%$, respectively, said the information was easily found (Table 1).

The subjects' self-assessment showed that teachers with and without visually impaired students often use the Internet to search for information on educational practices (53.3\% and $68.4 \%$, respectively). These teachers find it easier to access the Internet from home $(65.5 \%$ and $73.7 \%$, respectively) than from their schools (Table 1 ).

Having received previous guidance in the use of optical devices showed no correlation with teaching visually impaired students or not. Ad hoc orientation was the predominant source of guidance for both groups of teachers (41.9\% and $42.1 \%$ ), while a significant

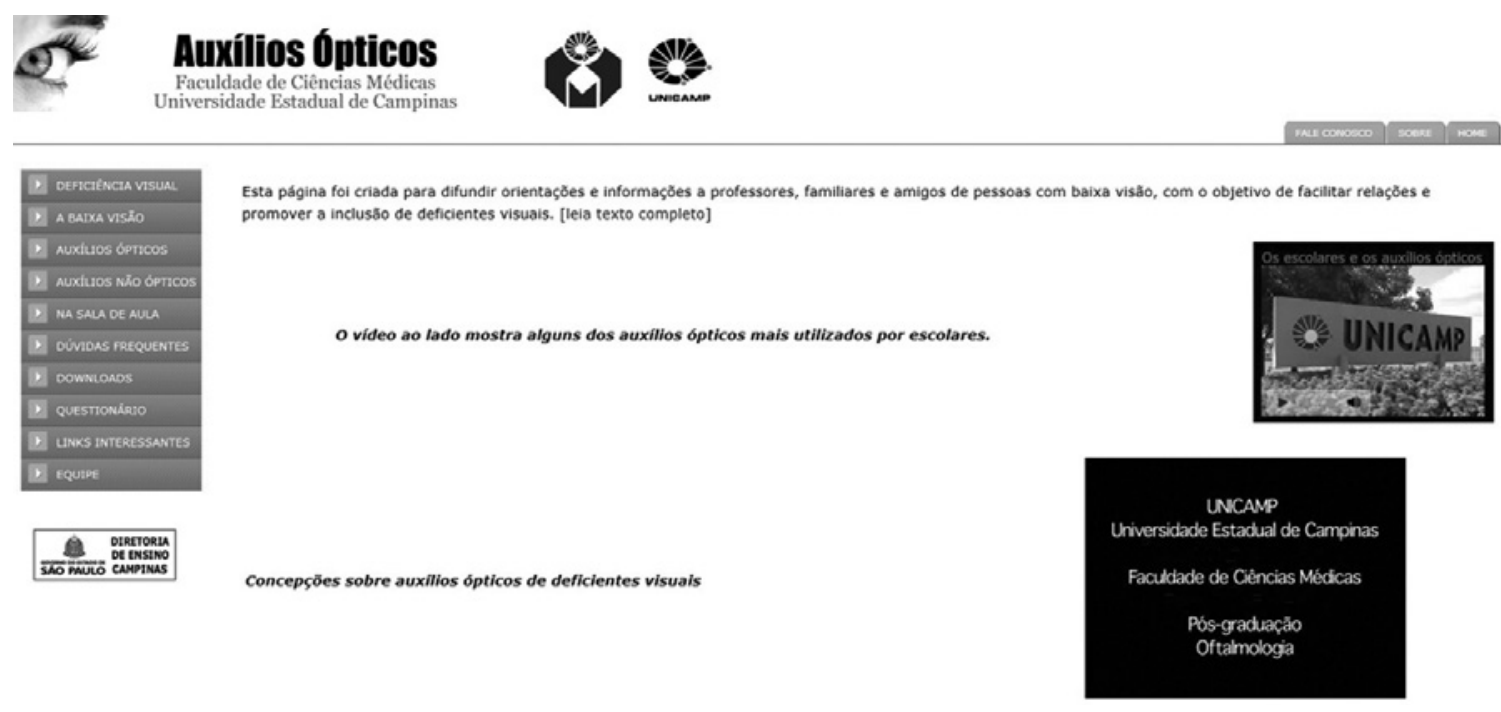

Figure 1. Optical Aids website (www.auxiliosopticos.fcm.unicamp) [in Portuguese]. 
Table 1. Views of elementary school teachers with and without visually impaired students about a web-based optical aid program and use of the Internet in education

\begin{tabular}{|c|c|c|c|}
\hline \multirow[b]{2}{*}{ Opinion } & \multicolumn{2}{|c|}{ Teachers } & \multirow[b]{2}{*}{$\mathbf{p}^{*}$} \\
\hline & $\begin{array}{l}\text { Classes with } \\
\text { visually impaired } \\
\text { children } \\
\%\end{array}$ & $\begin{array}{l}\text { Classes without } \\
\text { visually impaired } \\
\text { children } \\
\%\end{array}$ & \\
\hline Interest for the program & $(n=32)$ & $(n=19)$ & \\
\hline High & 81.3 & 73.7 & \\
\hline Reasonable & 15.6 & 21.1 & \\
\hline Low & 3.1 & 5.3 & 0.861 \\
\hline None & - & - & \\
\hline $\begin{array}{l}\text { Easiness/difficulty } \\
\text { to find information }\end{array}$ & $(n=32)$ & $(n=19)$ & \\
\hline Easy & 64.5 & 73.7 & \\
\hline $\begin{array}{l}\text { Neither easy nor } \\
\text { difficult }\end{array}$ & 25.8 & 15.7 & \\
\hline Difficult & - & 5.3 & \\
\hline No opinion & 9.7 & 5.3 & 0.544 \\
\hline Previous orientation & $(n=31)$ & $(n=19)$ & \\
\hline Yes, courses & 12.9 & 10.5 & \\
\hline $\begin{array}{l}\text { Yes, ad hoc } \\
\text { explanation }\end{array}$ & 41.9 & 42.1 & \\
\hline Yes, both & 6.5 & - & \\
\hline None & 38.7 & 47.4 & 0.829 \\
\hline $\begin{array}{l}\text { Internet use in teaching } \\
\text { practice }\end{array}$ & $(n=30)$ & $(n=19)$ & \\
\hline Frequent & 53.3 & 68.4 & \\
\hline Seldom & 33.3 & 26.3 & \\
\hline None & 13.3 & 5.3 & 0.574 \\
\hline Easy Internet access & $(n=29)$ & $(n=19)$ & \\
\hline At school & 31.0 & 10.5 & \\
\hline At home & 65.5 & 73.7 & \\
\hline Other locations & - & 10.5 & \\
\hline No easy access & 3.5 & 5.3 & 0.122 \\
\hline
\end{tabular}

* $=$ Fisher's exact test

proportion of teachers from both groups (38.7\% and 47.4\%) reported a total absence of any guidance (Table 1).

- The views obtained from the qualitative study, by means of the focal group are summarized below.

- The Internet is mainly used to search for content and is an established working tool, as shown by some statements like:

"I use the Internet to search for content."

"I cannot escape this daily contact with the Internet because it has become a working tool"

- Subjects said they need more information about low vision:

"During our college years, we do not receive orientation about how to work with these issues in the classroom..."

"The teacher is not prepared for that, no one is..."

- They also mentioned they cannot rely completely on the information obtained through the Internet:

"You do not always know if the website is reliable."

- They mentioned the families'resistance to the use of optical aids by the student, school dropout rates and misconceptions about low vision:
"The mother does not accept her girl's visual impairment and does not want her to attend the resource room."

"The mother took the girl out of school."

- They identified technological limitations in schools and lack of familiarity with the tool as factors discouraging access to the Internet.

"We have a computer room that has been out of use due to repairs..."

"We had no Internet access for the past three days... actually, no phone and no Internet..."

\section{DISCUSSION}

The level of interest for the Optical Aids website expressed by most of the teachers (Table 1) demonstrates the importance of this source of guidance as a tool to provide better educational assistance to students with visual impairment.

With respect to content and presentation of the Optical Aids website, most respondents expressed favorable opinions about the ease of finding information, which suggests the site is a valid tool to update and guide teachers about the use of optical aids (Table 1).

Most of the subjects said they had received prior ad hoc explanations or no explanation at all about the use of optical aids, which is consistent with research findings of other authors from the same region of the country, who showed that teachers had little specific information about visually impaired students ${ }^{(11)}$.

The communication of guidelines on how to deal with the visually impaired through the Internet faces personal and external barriers. While teachers often use the Internet in educational practice, the technology is not always available in schools (Table 1).

This reality affects some teachers, but many are used to accessing the Internet from home, and the Web is already part of their daily life, as it is with the general population, representing a routine communication channel.

The dissemination of information through the Internet can promote public health at a reasonable cost, because it is increasingly available for people of different socioeconomic levels. Even those who have not mastered this technology may be physically and socially close to the Internet through the help of family and friends ${ }^{(13,14)}$. Of note is the proportion of respondents who reported accessing the Internet more often from home than from their school, therefore in their familiar and friendly surroundings (Table 1).

The views gathered in the focus group discussion demonstrated the interest in the website. They also corroborate the need for more information on visual impairment as stated by teachers, who feel unprepared to teach students with low vision. Consistent with these results, previous studies have reported little specific preparation for teachers working with visually impaired students and have recommended the continued education of these professionals as a prerequisite for the educational integration of visually impaired students ${ }^{(5)}$.

On the other hand, reservations about the reliance on information obtained through the Internet and the compliance with guidelines thus received indicate the importance of hosting the site at public universities and providing referenced and reliable content.

Resistance to following guidelines may be modified by expanding knowledge, i.e. if the primary source (the consultation with the ophthalmologist) is complemented by information from various other sources (rehabilitation services, universities), then the behavioral change and acceptance are more likely, while misconceptions and the concealment of personal limitations are reduced.

Surveys of what people know or want to know about vision loss showed that individuals and groups gain independence when they are fully aware of their potential to prevent diseases and their ability to understand their health conditions ${ }^{(15)}$.

The use of Internet in the preparation of teachers of the visually impaired has been common in countries where new technologies have allowed equal access to electronic and print media ${ }^{(16,17)}$. 
The results of this study showed that there is frequent use of the Internet and that there is strong interest in finding information. However, the difficulty of Internet access in schools should be considered an important limitation to the intended dissemination of information on the use of optical aids. Nevertheless, while it does not invalidate the initiative, other actions are required to positively influence and facilitate the incorporation of new technologies in the school environment.

Teachers'training requirements to deal with visually impaired students and their willingness to receive advice and information lead to the conclusion that there is merit in publishing guidelines on the use of optical aids on a website, as a tool to promote the understanding of visual impairment and low vision rehabilitation ${ }^{(18,19)}$.

\section{REFERENCES}

1. World Health Organization. Consultation development of Standards for characterization of visual loss and visual functioning. Genève: WHO; 2003.

2. Carvalho KM, Monteiro GB, Rodrigues IC, Shiroma LO, Amaral MS. Causes of low vision and use of optical aids in the elderly. Rev Hosp Clín Fac Med S. Paulo. 2004:59(4):157-60.

3. Carvalho KM, Gasparetto ME, Venturini NH, Kara-José N. Visão subnormal: orientações ao professor do ensino regular. 3a ed. Campinas: Editora da Unicamp; 2002.

4. United Nations Educational, Scientific and Cultural Organization. Salamanca Declaration and framework of action. Geneva: UNESCO; 1994. 47 p.

5. Alves CC, Monteiro GB, Rabello S, Gasparetto ME, Carvalho KM. Assistive technology applied to education of students with visual impairment. Rev Panam Salud Publica. 2009;26(2):148-52.

6. Monteiro GB, Temporini ER, Carvalho KM. Use of optical aids by visually impaired students: social and cultural factors. Arq Bras Oftalmol. 2006;69(4):503-7.
7. Mercer D. Project VISION: An experiment in effective pedagogy for delivering preservice training to professionals in visual impairment through distance education. Teacher Education and Special Education. J Teach Educ. 2004;27:68-74.

8. Steele R, Mummery KW, Dwyer T. Development and process evaluation of an internet-based physical activity behavior change program. Patient Educ Couns. 2007; 67(1-2):127-36

9. Ferney SL, Marshall AL. Website physical activity interventions: preferences of potential users. Health Educ Res. 2006;21(4):560-6.

10. Nordqvist C, Harberger L, Timpka T, Nordfeldt S. Health professionals' attitudes towards using a web 2.0 portal for child and adolescent diabetes care: qualitative study. J Med Internet Res. 2009;11(2): e12.

11. Montilha RC, Temporini ER, Nobre MI, Gasparetto ME, Kara-José N. Utilization of optical devices and equipments by students with visual impairment. Arq Bras Oftalmol. 2006;69(2):207-11

12. Turato ER. Qualitative and quantitative methods in health: definitions, differences and research subjects. Rev Saúde Pública. 2005;39(3):507-14.

13. Lenhart A. The ever-shifting Internet population [Internet]. Pew Internet \& American Life Project. April 16, 2003; [cited 2011 Jun 21]. Available from: http:/www.pewinternet.org

14. Graham AL, Abrams DB. Reducing the cancer burden of lifestyle factors: opportunities and challenges of the Internet. J Med Internet Res. 2005;7(3):e26.

15. Janiszewski R, Heath-Watson S, Semidey AY, Rosenthal AM, Do Q. The low visibility of low vision: increasing awareness through public health education. J Vis Impair Blind. 2006; Special Suppl:849-61.

16. Corn AL, Hatlen P, Ponchillia PE. On the future of the field of education of students with visual impairments. J Vis Impair Blind. 2007;101(2):741-3.

17. Huebner KM, Wiener WR. Distance Education in 2001. J Vis Impair Blind. 2001:95(9): 517. 18 - Hubley J, Gilbert G. Eye health promotion and the prevention of blindness in developing countries: critical issues. Br J Ophthalmol. 2006:90(3):279-84.

19. Street AF, Swift K, Annells M, Woodruff R, Gliddon T, Okley A, et al. Developing a webbased information resource for palliative care: an action-research inspired approach. BMC Med Inform Decis Mak. 2007:7-26.

\title{
VI Congreso da ALACCSA-R \\ Associacion Latinoamericana de Cirujanos de Catarata, Segmento Anterior y Refractiva
}

\author{
4 a 6 de outubro de 2012
}

Hotel Hilton Puerto Madero

Buenos Aires - Argentina

Informações:

Site: www.alaccsa-r.com

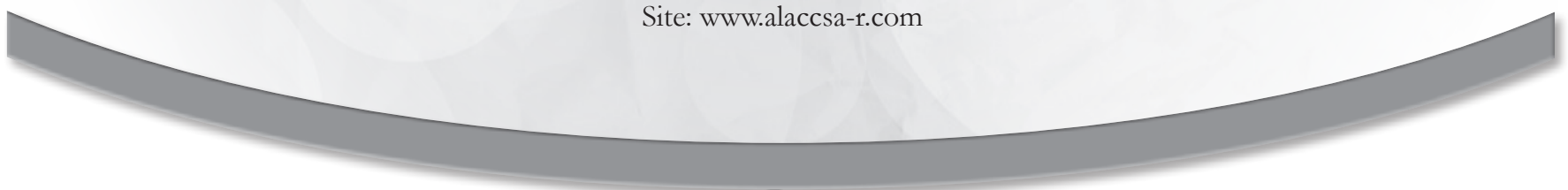

